\title{
In Vivo Toxicity Assessment of Bovine Serum Albumin and Dimercaptosuccinic Acid Coated $\mathrm{Fe}_{3} \mathrm{O}_{4}$ Nanoparticles
}

\author{
Parisa Hajshafiei ${ }^{1, *}$; Soheil Fatahian ${ }^{1}$; Kahin Shahanipoor ${ }^{1}$ \\ ${ }^{1}$ Falavarjan Branch, Islamic Azad University, Isfahan, I.R. IRAN \\ ${ }^{*}$ Corresponding author: Parisa Hajshafiei, Falavarjan Branch, Islamic Azad University, Isfahan, I.R. IRAN. Tel:+98-3117420134, Fax:+98-3117420134, E-mail: pshafiei14@yahoo.com
}

Received: December 14, 2013; Revised: January 23, 2014; Accepted: February 16, 2014

\begin{abstract}
Background: Recently, applications of nanoparticles in many fields of medicine have developed, due to their specific physical and chemical properties. Therefore, assessment of their toxicity especially in in vivo conditions is necessary.

Objectives: The aim of this study was to compare the toxicity of $\mathrm{Fe}_{3} \mathrm{O}_{4}$ nanoparticles coated with biocompatible compounds and noncoated nanoparticles.

Materials and Methods: Wetted chemical method was used in order to synthesize $\mathrm{Fe}_{3} \mathrm{O}_{4}$ nanoparticles. The synthesized nanoparticles were coated with BSA (Bovine Serum Albumin) and DMSA (Dimercaptosuccinic Acid) and the coating interactions were investigated by FTIR. Magnetic and structure properties of $\mathrm{Fe}_{3} \mathrm{O}_{4}$ and coated $\mathrm{Fe}_{3} \mathrm{O}_{4}$ nanoparticles were evaluated by AGFM (Alternating Gradient Force Magnetometer), TEM (Transmission Electron Microscope) and XRD (X Ray Diffraction). Toxicity assessment of $\mathrm{Fe}_{3} \mathrm{O}_{4}$ and coated $\mathrm{Fe}_{3} \mathrm{O}_{4}$ nanoparticles were studied in mice by intra peritoneal injections during a one-month period. Liver enzymes (SGPT, SGOT, ALP, and LDH) were measured 7,15 and 30 days post injection.

Results: The synthesized nanoparticles have a single phase and spinel structure; their size distribution in the net form is around 5 to $11 \mathrm{~nm}$ and in the coated form is 17 to $25 \mathrm{~nm}$. Some mice liver enzymes were changed due to the injection of both uncoated and coated nanoparticles (especially in groups which received concentrations of more than $100 \mathrm{mg}$ per $\mathrm{kg}$ of mice weight). Liver enzyme changes were more considerable in groups that received DMSA or DMSA coated nanoparticles in comparison with those that received BSA or BSA coated nanoparticles. Chemical toxicity studies showed that there was no irreversible effect with concentrations less than $200 \mathrm{mg} / \mathrm{kg}$ for all control and treated groups.

Conclusions: The results indicated that liver enzymes were changed during seven and 15 days post injection, especially with high doses $(200 \mathrm{mg} / \mathrm{kg})$. The results of measurements 30 days post injection showed less change in comparison with the control and this indicates that there was no irreversible effect on the liver. Moreover, DMSA coated nanoparticles were more toxic in comparison with BSA coated nanoparticles.
\end{abstract}

Keywords: Bovine Serum Albumin; DMSA; Nanoparticle

\section{Background}

Nanoparticles have high surface to volume proportion in comparison with bulk samples and this unique characteristic has made them appropriate for many medical and industrial applications. There are considerable studies on vast application of $\mathrm{Fe}_{3} \mathrm{O}_{4}$ nanoparticles such as cancer therapy, drug delivery $(1,2)$ MR imaging (3) and biotechnology (4). There are many methods that can be used for synthesizing nanoparticles such as the non-alkoxide sol-gel method, low temperature solid-state reaction and the microwave method (5-8). Nanoparticles are usually smaller than biological structures such as cells, viruses, proteins or genes. This small size makes them adequate for fast distribution in many tissues and considerable for the cellular uptake phenomenon (9). Recently, nanoparticles were coated with biocompatible materials in order to increase their stability in blood circulation and bio- logical organs. There are many materials, which are used for coating such as BSA (Bovine serum albumin), DMSA (Dimercaptosuccinic Acid $\mathrm{C}_{4} \mathrm{~S}_{2} \mathrm{O}_{4} \mathrm{H}_{6}$ ), dextran, polyethylene glycol, chitosan and aspartic acid (10-13). Presence of these coatings on the surface of nanomaterials increases cell entrance and reduces their toxicity effects (14). There are a limited number of studies on $\mathrm{Fe}_{3} \mathrm{O}_{4}$ toxicity especially under in vivo conditions and also, some studies have reported controversial results. As an illustration, some researchers have reported non-toxicity under in vivo conditions while some others have shown minimal toxicity at the same concentrations (14-17). Moreover, it is interesting to assess $\mathrm{Fe}_{3} \mathrm{O}_{4}$ toxicity in the presence of specific coating compounds separately by considering the variety of biocompatible materials (14). Therefore, it seems essential to investigate the toxicity effects of $\mathrm{Fe}_{3} \mathrm{O}_{4}$ 
nanoparticles and coated $\mathrm{Fe}_{3} \mathrm{O}_{4}$ nanoparticles under both in vitro and in vivo conditions. Bovine serum albumin is a serum albumin protein derived from cows. It is often used as a protein concentration standard. It is a globular protein that is used in numerous biochemical applications due to its stability and lack of interference within biological reactions. Dimercaptosuccinic acid is a nontoxic substance that has recently been used for some patients in order to absorb additional elements of the body (chelating agent) (15). Using these substances creates an anionic coating around the nanoparticle surface and prevents opsonization (accumulation of blood proteins around the nanoparticle). Therefore, these coating materials can potentially help nanoparticles by allowing stability in blood circulation and less deletion by the reticuloendothelial system of the liver and spleen. In fact, the presence of these substances on the surface of nanomaterials decreases direct contact with cells and cellular components, which lead to reduction of toxicity effects. Moreover, they increase tissue distribution and cell absorption (17).

\section{Objectives}

In this study an attempt was made to evaluate the effect of BSA and DMSA (as a coating on the surface of $\mathrm{Fe}_{3} \mathrm{O}_{4}$ nanoparticles) on the toxicity effects of $\mathrm{Fe}_{3} \mathrm{O}_{4}$ nanoparticles.

\section{Materials and Methods}

\subsection{Synthesis of $\mathrm{Fe}_{3} \mathrm{O}_{4}$ Nanoparticles}

$\mathrm{Fe}_{3} \mathrm{O}_{4}$ nanoparticles were synthesized by the wetted chemical method. In this method, three solutions of $\mathrm{FeCl}_{2}$ (0.01 M equals to $1.98 \mathrm{~g}$ ), $\mathrm{FeCl}_{3}$ (0.02 M equals to 5.41 g) and $\mathrm{NaOH}$ ( $0.08 \mathrm{M}$ equals to $3.2 \mathrm{~g}$ ) (all from the Merck company) were prepared in distilled deionized water. For this purpose, $\mathrm{FeCl}_{2}$ solution was poured into a triple neck round balloon and meanwhile, $\mathrm{FeCl}_{3}$ solution was added to the same balloon, under vigorous magnetic stirring. Next, every three to four seconds, one droplet of ME (Mercaptoethanol) solution was added via a magnetic stirrer. Finally, $\mathrm{NaOH}$ solution was added to the balloon in the same way. The resulting solution was washed by deionized water and was then centrifuged in order to remove any aggregate as impurity. All processes were done at room temperature (18).

$$
\mathrm{FeCL}_{2}+2 \mathrm{FeCL}_{3}+8 \mathrm{NaOH} \rightarrow \mathrm{Fe}_{3} \mathrm{O}_{4}+4 \mathrm{H}_{2} \mathrm{O}+8 \mathrm{NaCL}
$$

\subsection{Coating of $\mathrm{Fe}_{3} \mathrm{O}_{4}$ Nanoparticles with $\mathrm{BSA}$ and DMSA}

Primarily, 0.5 gr of BSA was diluted to $50 \mathrm{ml}$ in normal saline and the solution was added to $100 \mathrm{ml}$ of previously prepared $\mathrm{Fe}_{3} \mathrm{O}_{4}$ solution and the interaction was allowed to proceed for three hours under rapid stirring with ul- trasonic radiation. The coated nanoparticles were separated from uncoated nanoparticles and extra BSA by centrifugation for 30 minutes. Next, for more accuracy, 100 $\mathrm{ml}$ of distilled water was added and the centrifugation was repeated. The same processes were done in order to prepare the DMSA coated $\mathrm{Fe}_{3} \mathrm{O}_{4}$ nanoparticles except for the ultrasonic process which was done for only one hour. All processes were done at room temperature $(18,19)$.

\subsection{Quality assurance and measurement of prop- erties of the samples}

XRD (X-Ray Diffraction, Bruker D8 ADVANCE $\lambda=0.154$ $\mathrm{nm} \mathrm{Cu} \mathrm{K \alpha}$ radiation) was used in order to evaluate the size and crystalline structure. The accelerating voltage and the applied current were $40 \mathrm{kV}$ and $40 \mathrm{~mA}$, respectively. Data were recorded at a scan rate for two seconds in steps of 0.04 for $2 \theta$. The crystalline size was calculated by X-ray line broadening analysis using the DebyeScherrer equation for the full-width at half-maximum of the strongest reflection. Where, $\mathrm{D}$ is the crystalline size in $\mathrm{nm}, \lambda$ is the $\mathrm{Cu}-\mathrm{K} \alpha$ wavelength $(0.154 \mathrm{~nm}), \beta$ is the halfmaximum breadth, and $\theta$ is the Bragg angle of the (311) plane (20):

$$
D=\frac{0.9 \lambda}{\beta \cos \theta}
$$

Room temperature magnetization measurements up to a maximum field of 10 kOe were carried out using AGFM (Alternating Gradient-Force Magnetometer, Meghnatis Daghigh Kavir Co, Iran). TEM (Transmission Electron Microscope) was used for evaluating size and size distribution (12). The coating chemical interactions were assessed by FTIR (Fourier Transform Infrared Spectroscopy, JASCO FT/IR-680 PLUS) (21).

\subsection{Nanoparticles Injection to Mice}

For this step, 240 mice of Balb/c strain were obtained from the Razi Vaccine and Serum Research Institute. They were three months old and were kept in natural light and humidity at $22-24^{\circ} \mathrm{C}$. They were divided into 16 equal groups (each group contained 15 mice). One group was injected with normal saline and served as the control group and the 15 remaining groups received $\mathrm{Fe}_{3} \mathrm{O}_{4}$, DMSA, BSA, $\mathrm{Fe}_{3} \mathrm{O}_{4}$ with DMSA and $\mathrm{Fe}_{3} \mathrm{O}_{4}$ with BSA. Different concentrations of 50, 100 and $200 \mathrm{mg}$ per $\mathrm{kg}$ of mice weight were intra-peritoneally injected. Animal studies were performed in accordance with regulatory guidance on the care and use of experimental animals. Mice weights were measured and recorded at the time of injection and every week for up to one month.

\subsection{Measurement of Liver Factors}

Blood samples were taken directly from the heart under mild anesthesia with ketamine at time intervals 
Hajshafiei P et al.

of 7, 15 and 30 days post injection. Blood samples were poured into special pipes, which contained EDTA (Edetic Acid) anticoagulant agent. Then, liver factors such as SGPT (Serum Glutamic Pyruvate Transaminase), SGOT (Serum Glutamic Oxaloacetic Transaminase), LDH (Lactate Dehydrogenase) and ALP (Alkaline phosphatase) were measured by an automatic analyzer (RA1000 Technicon, America).

\subsection{Statistical Analysis}

For all groups, the mean values of liver factors (with treatment dose segregation) were compared by the ANOVA test (analysis of variance) and t-test using the Statistical Package for Social Sciences (SPSS) (version 15) computer program. Results are the mean values of five separate experiments for each group.

\section{Results}

\subsection{Physical Properties and Quality Assurance of Coated Fe3O4 Nanoparticles}

The structure of all samples was assessed by XRD. Figure 1 indicates the XRD pattern of uncoated, DMSA coated and BSA coated $\mathrm{Fe}_{3} \mathrm{O}_{4}$ nanoparticles. As presented by the figure, all samples have a single phase and ferrite spinel structure. The intensity of XRD background towards the peak is higher in the sample coated with BSA in comparison with that coated by DMSA. This is probably due to the DMSA and BSA structures. The mean size of the particles was determined by the Debye-Scherer formula. It was calculated as $11 \mathrm{~nm}$ for uncoated $\mathrm{Fe}_{3} \mathrm{O}_{4}$ nanoparticles, $17 \mathrm{~nm}$ for DMSA coated and $25 \mathrm{~nm}$ for BSA coated $\mathrm{Fe}_{3} \mathrm{O}_{4}$ nanoparticles.

TEM photograph of the uncoated $\mathrm{Fe}_{3} \mathrm{O}_{4}$ nanoparticles is shown in Figure 1. This photograph indicates that the sizes of the particles are around $10 \mathrm{~nm}$ with approximately uniform size distribution. This is compatible with the results of the XRD patterns (Figure 2) because the particle size increases with the coating process.

Magnetic properties of the nanoparticles were investigated by AGFM and it was proved that all samples were superparamagnetic. Figure 3 shows the uncoated, DMSA and BSA coated $\mathrm{Fe}_{3} \mathrm{O}_{4}$ nanoparticles results. The saturation magnetization was determined by extrapolation of the magnetization curve on the basis of when it was measured; 62, 27 and 23 emu/gr for uncoated, DMSA and BSA coated nanoparticles respectively (21).

FTIR curves of the $\mathrm{Fe}_{3} \mathrm{O}_{4}$, DMSA coated and BSA coated $\mathrm{Fe}_{3} \mathrm{O}_{4}$ nanoparticles are demonstrated in Figure 4. It can be observed that $1628 \mathrm{~cm}^{-1}$ and $3419 \mathrm{~cm}^{-1}$ peaks in the $\mathrm{Fe}_{3} \mathrm{O}_{4}$ curve, are related to $\mathrm{OH}$ junctions and it can be concluded that there is water molecules in the material structure. The $581 \mathrm{~cm}^{-1}$ peak indicates that the spinel structure was formed and we can see that it is compatible with the XRD curve results. Moreover, 1619 $\mathrm{cm}^{-1}$ and $1376 \mathrm{~cm}^{-1}$ peaks in DMSA coated $\mathrm{Fe}_{3} \mathrm{O}_{4}$ nanopar- ticles curve, are related to the asymmetry and symmetry stresses of the COO group, respectively. The fact that these peaks are in a close relation with the $1699 \mathrm{~cm}^{-1}$ and $1421 \mathrm{~cm}^{-1}$ peaks in the DMSA curve proves that the DMSA has coated the surface of the $\mathrm{Fe}_{3} \mathrm{O}_{4}$ nanoparticles. Furthermore, the $581 \mathrm{~cm}^{-1}$ peak decrease is another reason for this conjunction (20).

In the same way, it can be concluded that BSA has also coated the surface of the $\mathrm{Fe}_{3} \mathrm{O}_{4}$ nanoparticles. For instance, $2919 \mathrm{~cm}^{-1}$ and $3520 \mathrm{~cm}^{-1}$ peaks of the BSA coated $\mathrm{Fe}_{3} \mathrm{O}_{4}$ nanoparticles curve are the deformed peaks of $2923 \mathrm{~cm}-1$ and $3419 \mathrm{~cm}^{-1}$ of the $\mathrm{Fe}_{3} \mathrm{O}_{4}$ curve. The $588 \mathrm{~cm}^{-1}$ peak is related to the spinel structure which is the 581 $\mathrm{cm}^{-1}$ deformed peak in the $\mathrm{Fe}_{3} \mathrm{O}_{4}$ FTIR. The peak of 1495 $\mathrm{cm}^{-1}$ in the BSA coated $\mathrm{Fe}_{3} \mathrm{O}_{4}$ is related to the albumin conjunctions which is absent in the $\mathrm{Fe}_{3} \mathrm{O}_{4}$ and DMSA coated $\mathrm{Fe}_{3} \mathrm{O}_{4}$ FTIR. This is another reason for the accuracy of the coating process between the BSA and $\mathrm{Fe}_{3} \mathrm{O}_{4}$ nanoparticles.

\subsection{Liver Enzymes Measurement}

SGOT, SGPT, ALP and LDH liver enzymes were measured, 7,15 and 30 days post injection in all 16 groups. The results from day 7 and 15 are very similar and therefore the re sults from day 7 are not shown here. Figure 5, 6, 7 and 8 show the SGOT, SGPT, ALP and LDH measurement results 15 days post injection.

As indicated, there was no meaningful change in the groups, which received less than $100 \mathrm{mg} \cdot \mathrm{kg}^{-1} \mathrm{BSA}$, DMSA and uncoated $\mathrm{Fe}_{3} \mathrm{O}_{4}$ nanoparticles in comparison with the control. There was significant change in DMSA coated nanoparticles treated group even with 50 mg.kg-1 concentration yet BSA coated nanoparticles treated group showed meaningful change just with $200 \mathrm{mg} \cdot \mathrm{kg}^{-1}$ concentration (By considering the p-value being more than 0.05). Therefore, it can be concluded that BSA has high compatibility with biological systems.

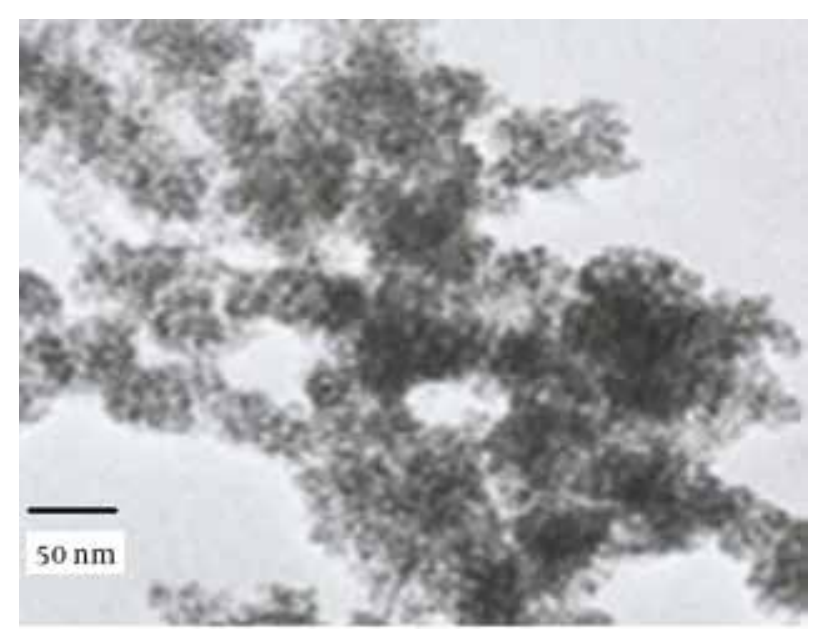

Figure 1. TEM Photograph of the Uncoated $\mathrm{Fe}_{3} \mathrm{O}_{4}$ Nanoparticles. 

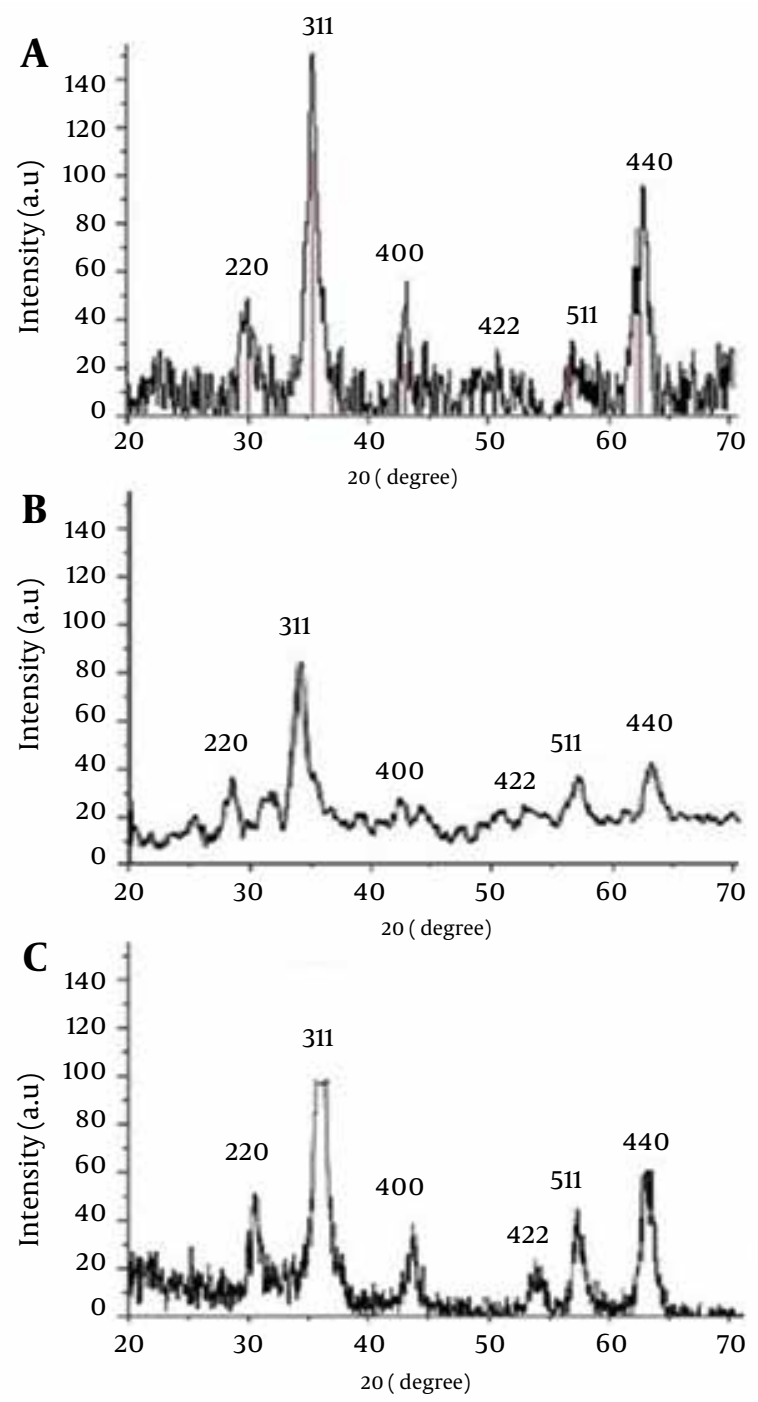

Figure 2. XRD Pattern. a: $\mathrm{Fe}_{3} \mathrm{O}_{4}$; b: DMSA coated $\mathrm{Fe}_{3} \mathrm{O}_{4}$; c: BSA coated $\mathrm{Fe}_{3} \mathrm{O}_{4}$

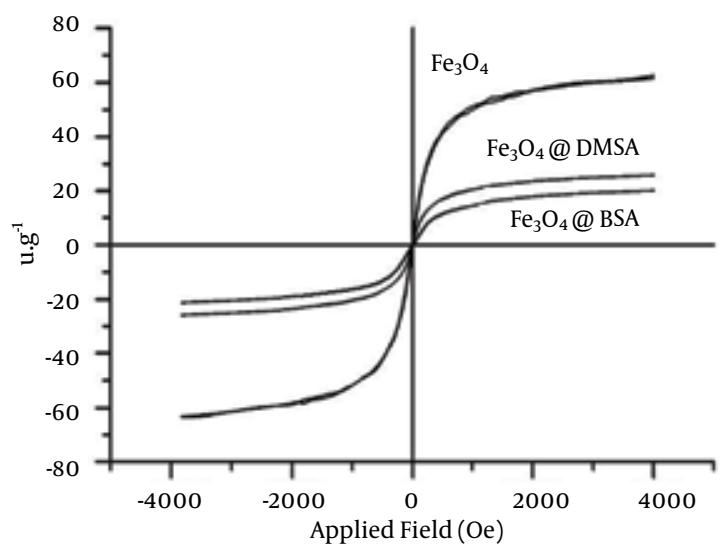

Figure 3. AGFM Curve of the Uncoated, DMSA and BSA Coated $\mathrm{Fe}_{3} \mathrm{O}_{4}$ Nanoparticles
Figures 9,10, 11 and 12 demonstrate the results of SGOT, SGPT, ALP and LDH liver enzymes measurements 30 days post injection. As indicated by the results there were less differences between the treated and control groups for all enzymes in comparison with that measured 7 and 15 days post injection. In the groups, which received albumin there was no meaningful difference even at high doses $\left(200 \mathrm{mg}^{\mathrm{kg}}{ }^{-1}\right)$. Moreover, at the concentration of $50 \mathrm{mg} \cdot \mathrm{kg}^{-1}$ there was no meaningful difference in all treated groups. These findings indicate that liver enzyme values intend to come back to normal limits after a month and most of the differences are reversible.

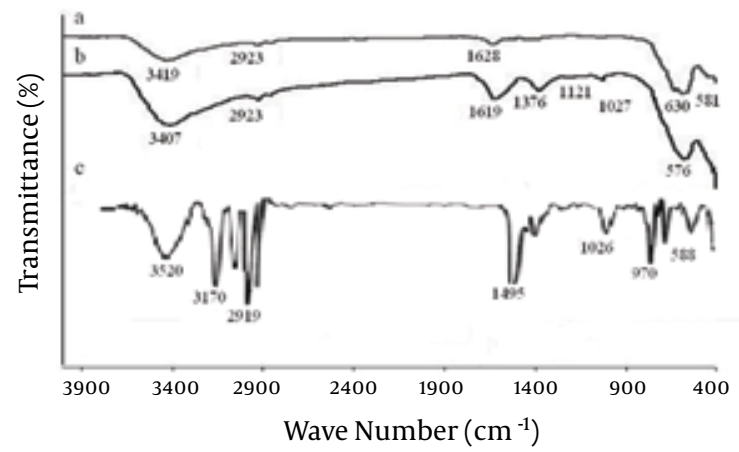

Figure 4. FTIR Curve

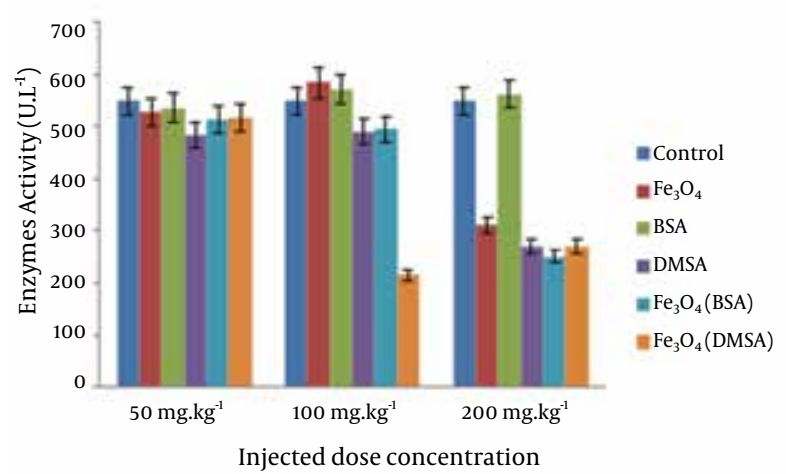

Figure 5. SGOT Measurement Results 15 Days Post Injection

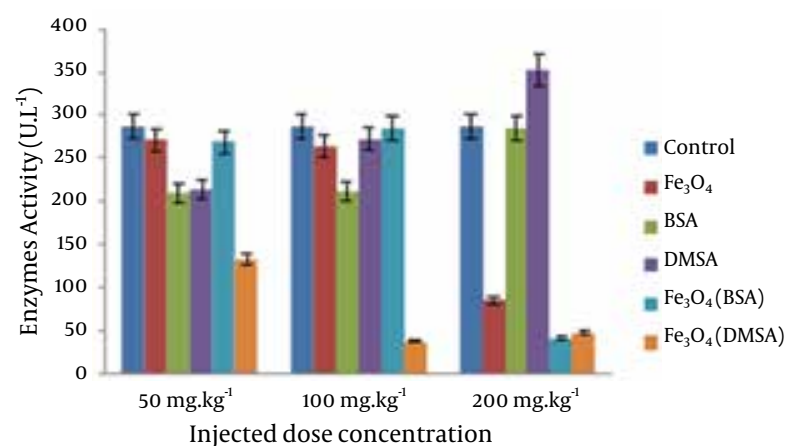

Figure 6. SGPT Measurement Results 15 Days Post Injection. 


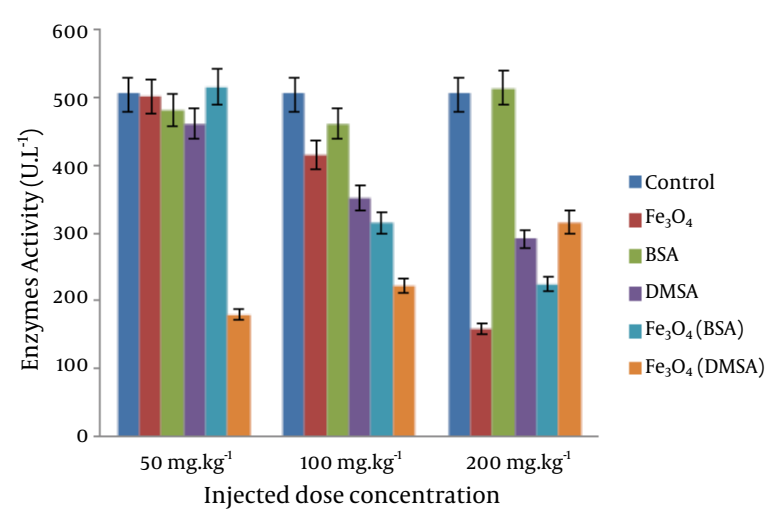

Figure 7. ALP Measurement Results 15 Days Post Injection.

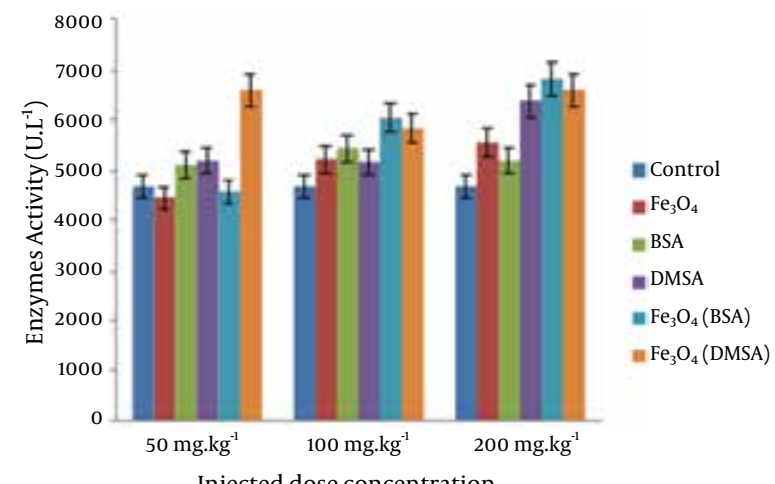

Figure 8. LDH Measurement Results 15 Days Post Injection.

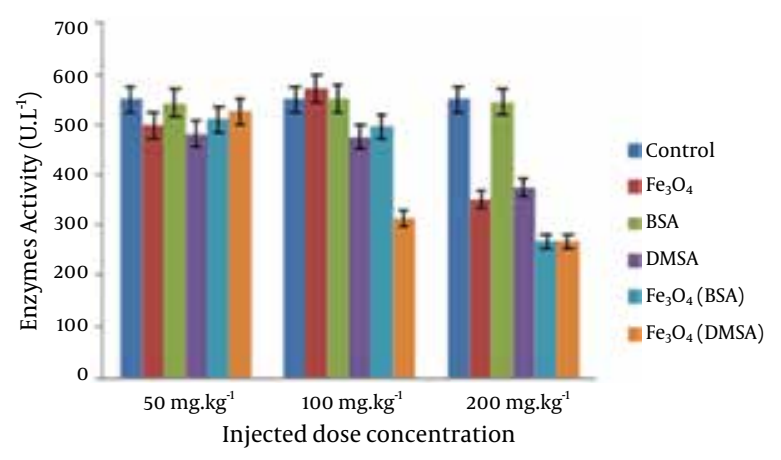

Figure 9. SGOT Measurement Results 30 Days Post Injection

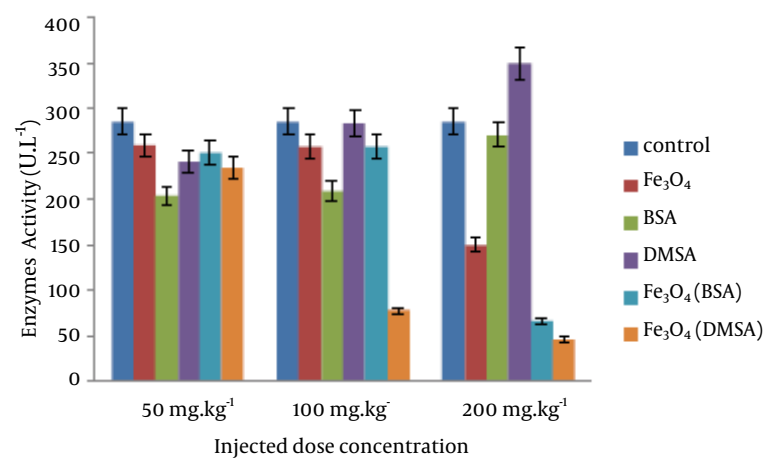

Figure 10. SGPT Measurement Results 30 Days Post Injection

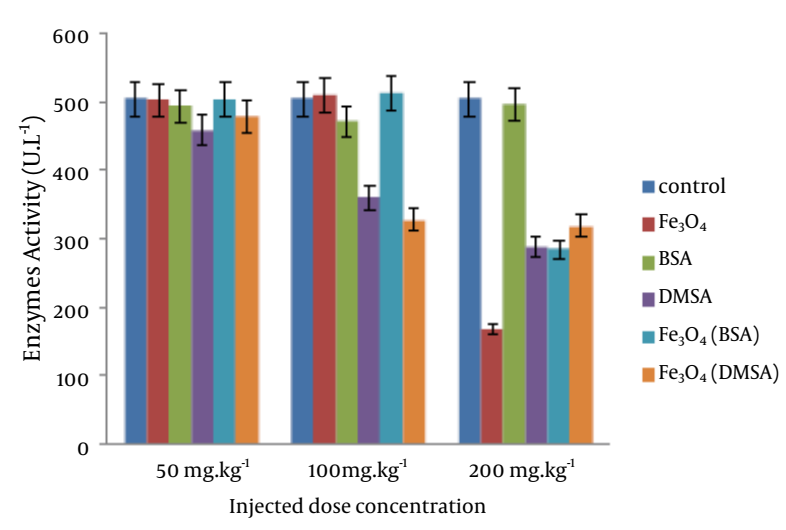

Figure 11. ALP Measurement Results 30 Days Post Injection

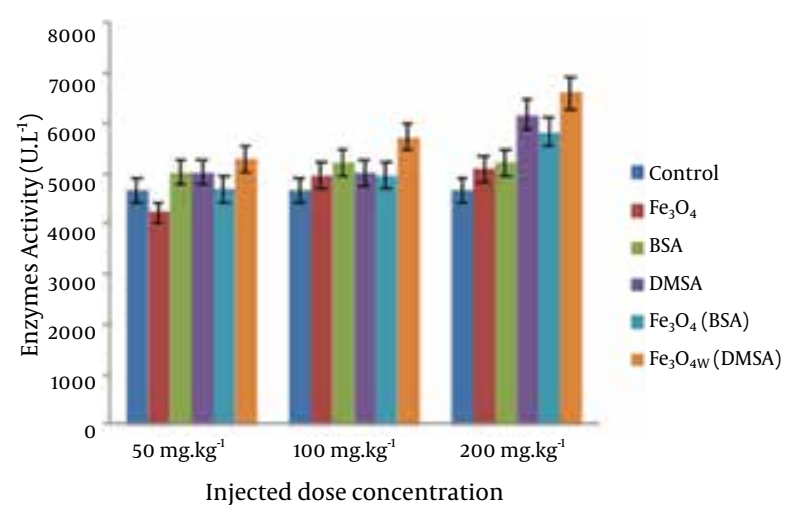

Figure 12. LDH Measurement Results 30 Days Post Injection

\section{Discussion}

The findings suggest that coated nanoparticles had greater affects on liver function in comparison with uncoated iron oxide nanoparticles. This probably occurred, due to their greater stability in blood circulation and consequently better penetration in different organs and cells. Therefore, it seems that the use of such coating materials (DMSA and BSA) on the surface of the $\mathrm{Fe} 3 \mathrm{O} 4$ nanoparticles increases their stability and side effects on liver enzymes. Also, considering the p-value, which is more than 0.05 for all variables, there was no significant change in mice's weights in all groups during the one-month period (results are not shown here). By surveying the results from 30 days post injection, it can be concluded that most values were returning to the normal limits and it is expected that all measured enzymes would return to normal values in the near future. This indicates that coated and uncoated iron oxide nanoparticles do not create any irreversible effect or disorder in liver function even at high doses (200 $\left.\mathrm{mg} \cdot \mathrm{kg}^{-1}\right)$. These results are very similar to that of Kim et al. where they injected less than $100 \mathrm{mg} \cdot \mathrm{kg}^{-1}$ concentrations of silica $\left(\mathrm{SiO}_{2}\right)$ coated nanoparticles $\left(\mathrm{CoFe}_{2} \mathrm{O}_{4}\right)$ intra-peritoneally into mice and realized the presence and distribution of nanoparticles in mice organs. No specific disorder 
Hajshafiei P et al.

was found in liver enzymes, 30 days post injection and also no weight changes were observed (17). Hafeli and Pauer intra spinally injected poly lactic acid coated $\mathrm{Fe}_{3} \mathrm{O}_{4}$ into rats. They didn't observed any mortality, toxicity or abnormality in animals' behaviors during the one year post injection. Animal's growth and weights were reported as normal (16). On the other hand, Sadeghiani et al. reported inflammatory responses due to intravenous injection of poly aspartic acid coated $\mathrm{Fe}_{3} \mathrm{O}_{4}$ nanoparticles into mice. Moreover, they observed that lymphocytes, monocytes and neutrophils increased and also some disorders in the maturation process of red blood cells occurred. These effects occurred during the first to 15th day post injection and remained for one month (14). In another study, intravenous injection of DMSA coated $\mathrm{Fe}_{3} \mathrm{O}_{4}$ nanoparticles into mice, entered the lungs (respiratory bronchioles and alveolar sac) while crossing the blood air dam and led to inflammatory responses, yet the severity of these changes reduced after three months (15). The most important and remarkable point, which is mentioned in most studies, is the small amount $\mathrm{Fe}_{3} \mathrm{O}_{4}$ nanoparticles usage in medicine, although they do not create any severe effects. In this study, the effects of intra-peritoneal injection of BSA and DMSA coated $\mathrm{Fe}_{3} \mathrm{O}_{4}$ nanoparticles (up to $200 \mathrm{mg} \cdot \mathrm{kg}^{-1}$ ) on mice's liver enzymes were assessed during a one-month period. The results indicate that most of liver enzymes changed meaningfully and significantly. However, this situation was temporary and returned to their normal range after a month. The findings seem to prove that coated iron oxide nanoparticles were more effective in comparison with uncoated nanoparticles. This phenomenon probably occurred due to their greater stability in blood circulation and consequently more penetration in different organs and cells. Moreover, DMSA coated nanoparticles were more toxic in comparison with BSA coated nanoparticles.

From the results of this study, in vivo, low concentrations of $\mathrm{Fe}_{3} \mathrm{O}_{4}$ nanoparticles (less than 200 mg.kg-1) do not create any serious or sever toxic effects. Furthermore, there was no meaningful change in mice's weight during the one-month post injection. According to controversial reports from different studies, it seems that more investigations with different biocompatible coatings are necessary.

\section{Acknowledgements}

The authors are grateful of Falavarjan Azad University for their cooperation and provision of the experimental equipment (most experimental results are from research code No.305/2231).

\section{Financial Disclosure}

There was no conflict of interest.

\section{Funding/Support}

The study was funded by Falavarjan Azad University.

\section{References}

1. Jayakumar OD, Ganguly R, Tyagi AK, Chandrasekharan DK, Nair CK. Water dispersible $\mathrm{Fe} 3 \mathrm{O} 4$ nanoparticles carrying doxorubicin for cancer therapy.J Nanosci Nanotechnol. 2009;9(11):6344-8.

2. Mahmoudi M, Sant S, Wang B, Laurent S, Sen T. Superparamagnetic iron oxide nanoparticles (SPIONs): development, surface modification and applications in chemotherapy. Adv Drug Deliv Rev. 2011;63(1-2):24-46.

3. Weissleder R, Elizondo G, Wittenberg J, Rabito CA, Bengele $\mathrm{HH}$, Josephson L. Ultrasmall superparamagnetic iron oxide: characterization of a new class of contrast agents for MR imaging. Radiology. 1990;175(2):489-93.

4. Bregy A, Kohler A, Steitz B, Petri Fink A, Bogni S, Alfieri A, et al. Electromagnetic Tissue Fusion Using Superparamagnetic Iron Oxide Nanoparticles: First Experience with Rabbit Aorta. Open Surg J. 2008;2:3-9.

5. Qi H, Yan B, Lu W, Li C, Yang Y. A Non-Alkoxide Sol-Gel Method for the Preparation of Magnetite (Fe3O4) Nanoparticles. Curr Nanosci. 2011;7(3):381-8.

6. Amiri G, Yousefi MH, Aboulhassani MR, Keshavarz MH, Shahbazi D, Fatahian S, et al. Radar absorption of Ni0.7Zno.3Fe2O4 nanoparticles. Dig J Nanomater Bios (DJNB). 2010;5(3):1025-31.

7. Amiri G, Yousefi MH, Abolhassani MR, Manouchehri S, Keshavarz $\mathrm{MH}$, Fatahian S. Magnetic properties and microwave absorption in Ni-Zn and Mn-Zn ferrite nanoparticles synthesized by low-temperature solid-state reaction.J Magn Magn Mater. 2011;323(6):730-4.

8. Amiri G, Fatahian S, Jelvani AR, Mousarezaei R, Habibi M. Magnetic Properties of CoFe2O4 and Co0. 5 Zno. 5Fe2O4 Ferrite Nanoparticles Synthesized by Mi crowave Method. Optoelectron Adv Mat. 2011;5(11):1178-80.

9. Salata O. Applications of nanoparticles in biology and medicine. $J$ Nanobiotechnology. 2004;2(1):3.

10. Kavitha AL, Prabu HG, Babu SA, Suja SK. Magnetite nanoparticleschitosan composite containing carbon paste electrode for glucose biosensor application. J Nanosci Nanotechnol. 2013;13(1):98-104.

11. Molday RS, MacKenzie D. Immunospecific ferromagnetic irondextran reagents for the labeling and magnetic separation of cells. J Immunol Methods. 1982;52(3):353-67.

12. Berry CC, Wells S, Charles S, Curtis AS. Dextran and albumin derivatised iron oxide nanoparticles: influence on fibroblasts in vitro. Biomaterials. 2003;24(25):4551-7.

13. Lacava LM, Lacava ZG, Da Silva MF, Silva O, Chaves SB, Azevedo RB, et al. Magnetic resonance of a dextran-coated magnetic fluid intravenously administered in mice. Biophys J. 2001;80(5):2483-6.

14. Sadeghiani N, Barbosa LS, Silva LP, Azevedo RB, Morais PC, Lacava ZGM. Genotoxicity and inflammatory investigation in mice treated with magnetite nanoparticles surface coated with polyaspartic acid.J Magn Magn Mater. 2005;289:466-8.

15. Garcia MP, Miranda Parca R, Braun Chaves S, Paulino Silva L, Djalma Santos A, Guerrero Marques Lacava Z, et al. Morphological analysis of mouse lungs after treatment with magnetite-based magnetic fluid stabilized with DMSA. J Magn Magn Mater. 2005;293(1):277-82.

16. Häfeli UO, Pauer GJ. In vitro and in vivo toxicity of magnetic microspheres. J Magn Magn Mater. 1999;194(1):76-82.

17. Kim JS, Yoon TJ, Yu KN, Kim BG, Park SJ, Kim HW, et al. Toxicity and tissue distribution of magnetic nanoparticles in mice. Toxicol Sci. 2006;89(1):338-47.

18. Fatahian S, Shahbazi Gahrouei D, Pouladian M, Yousefi MH, Amiri G, Noori A. Biodistribution and toxicity assessment of radiolabeled and DMSA coated ferrite nanoparticles in mice.J Radioanal Nucl Chem. 2012;293(3):915-21.

19. Keshavarz M, Ghasemi Z. Coating of Iron Oxide Nanoparticles with Human and Bovine Serum Albumins: A Thermodynamic Approach. J Phys Theor Chem. 2011;8(2):85-95.

20. Li F, Wang H, Wang L, Wang J. Magnetic properties of $\mathrm{ZnFe}_{2} \mathrm{O}_{4}$ nanoparticles produced by a low-temperature solid-state reaction method.J Magn Magn Mater. 2007;309(2):295-9.

21. Fatahian S, Shahbazi D, Pouladian M, Yousefi MH, Amiri GR, Shahi $Z$, et al. Preparation and magnetic properties investigation of $\mathrm{Fe}_{3} \mathrm{O}_{4}$ nanoparticles $99 \mathrm{mTc}$ labeled and $\mathrm{Fe}_{3} \mathrm{O}_{4}$ nanoparticles DMSA coated. Dig J Nanomater Bios. 2011;6(3):1161-5. 